\title{
The Effect of Contextual Factors on Resistance to Change in Lean Transformation
}

\author{
Duc Trong TRAN ${ }^{1}$, Huong Thu PHAM${ }^{2}$, Van Thu BUI ${ }^{3}$
}

Received: August 01, 2020 Revised: September 28, 2020 Accepted: October 05, 2020

\begin{abstract}
The purpose of this paper is to uncover whether and how contextual factors (information exchange, participation, trust in management, and training), relate to resistance to change. It also explores the mediating effect of perceived impact of change on the relations between contextual factors and resistance to change. This study is conducted in several manufacturing plants in food processing industry in Vietnam, which is implementing a top-down large-scale change - Lean transformation, adopting Total Productive Maintenance (TPM) program, to be specific. The findings suggest that all four contextual factors are negatively associated with resistance to change, in which training had the strongest impact. Also, the perceived change impact partially mediates the relationships between the four contextual factors and resistance to change. The practical implications of this paper are that employees who receive adequate, timely and useful information relating to change are less likely to show opposing behaviors towards change. Fostering trust in management among employees, and employee involvement in decisionmaking, also have a significant influence when addressing employee resistance to change. Employees who are well-trained, well-equipped with tools and knowledge about the change, are less likely to resist as they view the benefits of changes more significant than the risks.
\end{abstract}

Keywords: Resistance to Change, Information Exchange, Participation, Trust in Management, Training

JEL Classification Code: M10, M11, M12, M16

\section{Introduction}

Empirical and practitioner findings relating to change management indicated an unfavorable trend in successful change management over the last decade. Change failure rate was revealed to be at $70 \%$ in 2004 (Balogun et al., 2008); the figure remained constant in 2008 (Meaney \& Pung, 2008). A study targeting 1,500 change agents in 2009 found out that only $41 \%$ of change efforts were considered success (Jorgense et al., 2009). Until recently, the statistics

${ }^{1}$ First Author and Corresponding Author. Lecturer, School of Trade and International Economics, National Economics University, Vietnam [Postal Address: 207 Giai Phong, Hai Ba Trung District, Hanoi, 113068, Vietnam] Email: ductt@neu.edu.vn

${ }^{2}$ National Economics University, Vietnam.

Email: huongggthu1998@gmail.com

${ }^{3}$ Lecturer, Faculty of Business Management, National Economics

University, Vietnam. Email: vanbt@neu.edu.vn

(c) Copyright: The Author(s)

This is an Open Access article distributed under the terms of the Creative Commons Attribution Non-Commercial License (https://creativecommons.org/licenses/by-nc/4.0/) which permits unrestricted non-commercial use, distribution, and reproduction in any medium, provided the original work is properly cited. were not showing any improvement and still change efforts are failing at the rate of $70 \%$ (Michel et al., 2013; Al-haddad \& Kotnour, 2015).

When considering the specific context of Lean transformation, the change failure rate was reported to be even higher in various contexts. Bhasin and Burcher's (2006) findings show that less than $10 \%$ of organizations succeeded in implementing Lean tools. Recent studies, such as Schipper and Swets' (2010) and Jadhav et al. (2014) reported that $70 \%$ of Lean transformation cases failed in overcoming barriers, and returned to the previous ways of performing work. However, in the case of UK organizations, the success rates in Lean transformation remained at 10\% throughout the years (Camagu, 2010). Mohanty et al.'s (2007) survey findings indicated that US organizations, particularly in automobile industry, were struggling to imitate Toyota Production System to achieve operational efficiency. Singh et al. (2010) also reported the similar struggle of US firms in the context of India.

Extant research constantly cited resistance to change (RTC) from employees as one of the key problems for change failure (Huang \& Huang, 2009; Erwin \& Garman, 2010). Managing resistance is critical, determining whether the 
change implemented will be successful or not (Decker et al., 2012; Canning \& Found, 2015), since resistance has the power to slow and prevent change from happening (Coetsee, 1999). Therefore, resistance to change should be given sufficient attention by management, especially in the rapidly changing business environment when the needs to change are raised constantly. This paper aims to investigate antecedents of RTC (contextual factors, to be specific) to assist management make informed decision when dealing with RTC.

Considering the gap in the literature related to both contexts of Vietnam and quantitative research on Lean transformation, this study chose to investigate a single-case study in Lean transformation, in a manufacturing plant adopting one of the Lean tools, Total Productive Maintenance, in the food processing industry. Reviewing the literature on lean and resistance to change identifies four key employee factors when implementing Lean, namely, trust in management, training, information exchange, and participation (Cudney \& Elrod, 2010; Jadhav et al., 2014; Canning \& Found, 2015; Portioli-Staudacher \& Tantardini, 2012) are chosen as four contextual factors to analyze their relationships with RTC. The study also aims to fill the knowledge gap in studying the mediation effect of the perceived impact of change on the relationships between contextual factors and RTC.

In the following sections, the paper presents a literature review and the hypothesis development of the study, followed by the research methodology and then the research findings and discussions.

\section{Literature Review}

\subsection{Resistance to Change}

In the conventional view, organizational change is considered as desirable and inevitable, and people resisting it are irrational. This view implied that resistance should be managed and overcome (Mabin et al., 2001; Piderit, 2000; Atkinson, 2005). Dent and Goldberg (1999) proposed that individuals resist negative consequences (e.g., losing their jobs, disrupting daily works) and not necessarily the change in itself. Therefore, the conventional belief hinders organizations' holistic understanding of RTC.

Considering defining RTC issues, Jermier et al. (1994), Dent and Goldberg (1999) pointed out that RTC has been oversimplified, referring to any unfavorable reactions to prevent change. To better grasp the complexity of resistance, suggesting that a dichotomous perspective of employees' response to change (pure resistance and compliance) was too narrow, Piderit (2000) defined RTC as a tri-dimensional (negative) response towards change, which includes how individual feels about change (affective), intentions to act towards change (behavioral), and what they think about change (cognitive). In this study, RTC is examined in the behavioral dimension, which involves behaviors or intentions to behave responding to the change (e.g., protesting against change, presenting disagreement to upper management levels, etc.).

To examine employees' RTC, this study chose to investigate the concept from the perspective of change recipients referring to the group of people taking charge of implementing or adapting to changes (Jacobs \& Keegan, 2016; Kumari, 2017), since they are the most appropriate to measure their own perceived resistance (Armenakis \& Harris, 2009; Oreg et al., 2011). When reviewing extant literature on RTC, in their pioneering works, Coch and French (1948) initially proposed that potential sources of resistance come from both the individual and one's environment - contextual factors. However, owing to the reduced interest in field theory, papers followed focusing on the individual and how they reacted to change, and tend to omit contextual factors (Burnes, 2014). Consequently, works by Bovey and Hede (2001) and Weller and Bernadine (2007) increasingly refer to RTC as a psychological concept in which resistance is within individual employees. For instance, due to prevalence of Oreg's (2003) study in dispositional resistance concept, sources of RTC were increasingly viewed in terms of personality perspective, which leads to the lack of academic attention on contextual factors. Following Burnes' (2014) call for research focus on contextual factors to support for Coch and French (1948) and Lewin's (1947) system view of resistance, the paper aims to investigate RTC antecedents in contextual view, in Vietnam, where the investigation of RTC and its contextual antecedents is still highly limited.

Oreg et al. (2011) categorized contextual factors into four major types: (1) internal context antecedents involving prechange organizational environment including culture and climate, trust in management; (2) change process antecedents comprising participation, communication and information, and principal support during change; (3) perceived outcomes/ impact of change; and (4) change content antecedents (M\&A, downsizing). In the context of Vietnam, affected commitment, participation and communication were empirically investigated in several papers examining RTC in organizations conducting changes, in general. This paper fills the knowledge gap by re-testing the impact of participation and information exchange in a specific Lean case study and examining two narrowly investigated contextual factors trust in management and training in Vietnam (Trang \& Do, 2020).

Oreg et al. (2011) pointed out that, though the existing literature examined a plethora of RTC antecedents, the investigation of their interrelationships, including mediation analysis, should be taken into consideration as well. By addressing this knowledge gap, the paper studies the role of perceived impact of change mediating the relationship between contextual factors and recipients' resistance. There, contextual factors ultimately influence individual's anticipated benefits or risks of change, then, perceived 
impacts of change will in turn lead to attitudes and behaviors to change (Ashford, 1988; Cunningham et al., 2010; Bartunek et al., 2006). Specifically, one's behaviors toward change vary on the basis of whether expected benefits of change outweigh perceived risks. There is evidence in the extant literature that individuals perceiving organizational change posing considerable risks to their own or their organizations' routines or performance, experience greater stress, and consequently show opposing behaviors toward change (Herold et al., 2007; Fedor et al., 2006; Caldwell et al., 2004).

Reviewing existing literature, very few papers have investigated the mediating role of perceived impact of change on RTC, except Vakola (2014) who conducted mediation analysis of perceived impact of change between individual readiness to change and communication climate and job satisfaction in a restructuring change project. However, in Vakola's (2014) paper, readiness to change concept refers to "confidence in one's abilities to overcome the change", which is different from investigated the behavioral RTC concept in this paper.

\subsection{Resistance to Change in Lean Transformation}

The term "Lean" was first used by Womack et al. (1990) to describe an approach enabling firms to maximize customer value while minimizing waste by eliminating inefficient and unnecessary processes and enhancing the value chain (Womack \& Jones, 2003). The most commonly applied Lean tools include just-in-time, value stream map, total quality management, kaizen, and total productive maintenance (Marodin \& Saurin, 2013).

Though organizations widely implement Lean tools to achieve desired outcomes, the successful lean implementation rate was recognized to be significantly low, approximately $10 \%$ in various countries such as UK, India, and the US, as per the literature (Mohanty et al., 2007; Camagu, 2010; Singh et al., 2010), due to three key barriers involving cultural, human and geographical factors (Benton \& Shin, 1998). There, employee barriers to Lean implementation mostly relate to ineffective communication and inadequate information exchange between managers and employees (Cudney \& Elrod, 2010; Jadhav et al., 2014); lack of participation in decision-making from employees (Canning \& Found, 2015; Portioli-Staudacher \& Tantardini, 2012), lack of formal training to employees (Eswaramoorthi et al., 2011), and lack of mutual trust between employees and managers (Staudacher \& Tantardini, 2007). Specifically, Sim and Chiang (2012) and Azyan et al. (2017) identified key sources of employee resistance in lean program, which involves trust in management and negative perceived impact of change (increasing workload, being undervalued because of Lean).

However, reviewing the literature, the number of empirical studies on employee resistance in Lean case study is still limited, especially in Vietnam context. In Lean literature, the majority of papers on employee resistance adopts qualitative research, interviews to be specific, such as Sim and Chiang (2012) and Azyan et al. (2017). Also, only a few contextual factors such as communication and participation were empirically tested in Lean context (Canning \& Found, 2015). Therefore, this study fills the research gap by testing four key identified human barriers in Lean implementation - information exchange, participation, training, and trust in management, as factors affecting employee resistance in Lean case study in Vietnam.

\section{Hypothesis Development}

\subsection{Information Exchange}

Information exchange refers to the degree to which recipients perceive that the necessary and useful information relating to organizational change is provided, and this provided information must be exchanged timely and delivered effectively (Miller et al., 1994; Armenakis et al., 2007; Holt et al., 2007).

Previously empirical studies in extant literature have found that individuals equipped with necessary information display a higher level of likelihood to adapt to change (Schweiger \& DeNisi, 1991; Miller et al., 1994). Testing in the context of public housing sector, Wanberg and Banas' (2000) findings show a positive association between adequate information received about organizational change and one's openness to accept change. Lewis' (2006) study surveying undergraduates working part-time in organizations implementing new information technology program in various industries, also found that the better the perceived quality of received information, the lower the degree of one's resistance to change. On the contrary, Oreg (2006) shows that information received about change is positively correlated with recipients' resistance to change. He explained that recipients' intentions to resist change depend on whether they approve or disapprove the change, so information about the change may not have a positive impact to RTC. In the context of Vietnam, testing the relationship in organizations implementing changes in various industries suggested similar findings to Lewis' (2006).

Putting Lean transformation in the context, Cudney and Elrod (2010) and Scherrer-Rathje et al. (2009) addressed the importance of appropriately informing employees about the change to tackle resistance and raise the success rate of Lean implementation. For instance, if Lean's expected process and outcomes were not communicated well to all functional areas, employees in frontline may not be fully aware of the program, then it results in higher level of stress and increases the likelihood to oppose change, due to uncertainty and ambiguity of information (Jadhav et al., 2014; Schweiger \& Denisi, 1991).

H1a: Information exchange is negatively associated with resistance to change. 
Information exchange is considered to be vital when recipients assess and compare the benefits and risks relating to the change. To be specific, inadequate information may make "one's cognitive and affective processes to be negatively affected towards change" (Vakola, 2014), and consequently, the individual will be less likely to adapt to change and display disrupting behaviors. According to the literature, when helpful and timely information is properly delivered to employees, employees seem to view the change's impacts positively and show higher levels of openness to organizational change (Miller et al., 1994; Wanberg \& Banas, 2000, Vakola, 2014).

H1b: Perceived impact of change mediates the relationship between information exchange and employee resistance to change.

\subsection{Participation}

Participation is defined as employee involvement in the decision-making process in the development and implementation of the change, as well as the right to input decisions about the change's future plans (Lines, 2004; Giangreco \& Peccei, 2005, Wanberg \& Banas, 2000).

Looking into change management literature, Cornell and Herman (1989); Fiorelli and Margolis (1993); Wanberg and Banas (2000) unanimously argued that the impact of employee involvement in addressing resistance, particularly, when employees have the rights to input decisions, increased their commitment to the change, and resistance to change is reduced, accordingly. Giangreco and Peccei's (2005) research on RTC from middle managers' perspective in an electric company case study, found that there was a positive relation between recipients' participation level in change initiative and positive attitude towards change and reduced levels of resistance. Also, Lines' (2004) study in a restructuring project in a telecommunication case study and Msweli-Mbanga and Potwana's (2006) paper on state-owned companies in South Africa, come to similar conclusions.

Considering Lean context, Netland (2016) and Pakdil and Leonard (2015) consistently identified employee empowerment and encouragement to participate in decisionmaking as vital to the success of lean programs (especially when implementing continuous improvement) and effective when facing objections from employees, as it significantly motivates employees and increases their autonomy.

H2a: Employee participation is negatively associated with resistance to change.

Employee participation is argued to make the realities of the change clearer to employees (Lines, 2004) by offering them an effective way to voice their ideas and receive insightful information about the change (Msweli-Mbanga \& Potwana, 2006). By which, employees have a sense of control and are fully aware of the change's outcomes, which may result in positive perceived impacts of change. Consequently, employees will be more active toward change initiatives by inputting decisions, and less likely to resist the change (Jimmieson et al., 2008; Van Dam et al., 2008).

H2b: Perceived impact of change mediates the relationship between participation and employee resistance to change.

\subsection{Training}

Training in this study refers to all training programs and necessary tools and knowledge provided by the organization in the initial and implementation stages of the change program (Zahra et al., 2018). As this contextual factor received limited attention from existed empirical studies in change management literature, the hypothesis development would be based on the context of Lean transformation.

Throughout the literature on success factors and barriers to Lean implementation, employee's expertise and knowledge are vital to the success of Lean (Clegg et al., 2010; Dora et al., 2013). Thus, providing proper and timely training and education program is important to enhance employee's skills to manage the change (Pakdil \& Leonard, 2015). By being equipped with necessary tools and knowledge, employees would likely be more ready to change, leads to increased openness to change and reduced resistance to change.

Also, tools and knowledge provided in training programs are viewed to be important when employees evaluate benefitrisk analysis of the change initiative, as it plays a significant role in enhancing employees' capabilities, by which, they feel less threatened by the risk of change (e.g., losing jobs when implementing lean tools), in turn, reduces resistance.

H3a: Training is negatively associated with resistance to change.

H3b: Perceived impact of change mediates the relationship between training and employee resistance to change.

\subsection{Trust in Management}

Basing on Oreg's (2006) study, trust in management is defined as the degree to which recipients are confident in the management and leadership of management levels to lead successful change, also involves the beliefs that they could rely on managers to carry out what was beneficial to the organization and employees.

Throughout change management literature, studies consistently viewed trust in management as a vital antecedent to reduce recipient's resistance to change (Cunningham et al., 2010; Kiefer, 2005). To be specific, employees perceiving their managers as being competent to lead the change effectively and viewing their leaders as reliable and supportive, were more likely to show 
supportive behaviors to the change (Wanberg \& Banas, 2000; Eby et al., 2000). Oreg (2006) shows that a lack of trust in management significantly correlates with all three dimensions of resistance, including behavioral resistance. The study investigating Lean context also found similar results on the relationship between trust in management and resistance (Staudacher \& Tantardini, 2007).

H4a: Trust in management is negatively associated with resistance to change.

Basing on Lewis and Weigert's (1985) argument, trust influences "the decisional-balance process through employees' cognitive and affective processes", since "people choose whom we will trust in which respects and under any cases, and we make decisions on the basis of what we considered as good reasons, constituting evidence of trustworthiness". Consequently, employees portraying trust in their management, view organizational change more positively and therefore are less likely to oppose the change. This particular argument is formed on the basis of cognitive motivation research, in which "reduced effort is expected under circumstances of lower utility and/or lower valence outcomes" (Caldwell et al., 2004, Vakola, 2014).

H4b. Perceived impact of change mediates the relationship between trust in management and employee resistance to change.

\section{Research Methodology}

\subsection{Data Collection}

Quantitative method was applied, and self-reported survey data was collected. This data collection method is appropriate since the concepts of various antecedents of RTC are well established and defined clearly in extant literature (Oreg et al., 2011). Especially, scales developed for antecedents have long been empirically tested in different contexts (Oreg et al., 2011), which proves its construct validity. That is also the reasons why self-reported survey is the most common method used to study antecedents of RTC (Erwin \& Garman, 2010).

This study is conducted in manufacturing plants in food processing industry in Vietnam. The plants are implementing a large-scale organizational change, Lean transformation, by applying one of Lean key tools, Total Productive Maintenance (TPM). The change was originally top-down from top management in headquarters to plant levels. The plants have been going through Lean transformation more than five years and achieved TPM Excellent Award from Japan Institute of Plant Maintenance.

In this study, the case study design allows researchers to collect in-depth data on resistance to change in Lean transformation case in food processing industry solely.
A soft copy of questionnaire form via Google Doc link was sent to every worker in the manufacturing plants via internal communication networks, and 800 responded to the questionnaire. Since the nature of TPM program involves eliminating waste via autonomous maintenance, which mostly involves machine operators, and maintenance personnel and engineers in the plant, the study attempts to maintain the equal distribution in job positions percentage, in which plant workers and engineers account for $55 \%$ of sample size. Also, most respondents were in the 35-49 age group (46.3\% of sample size) and have been working for plants over a decade $(43.8 \%)$.

\subsection{Data Analysis}

To test H1a, H2a, H3a, H4a, relating to relationships between contextual antecedents and RTC, multiple regression analysis is performed.

To test $\mathrm{H} 1 \mathrm{~b}, \mathrm{H} 2 \mathrm{~b}, \mathrm{H} 3 \mathrm{~b}, \mathrm{H} 4 \mathrm{~b}$, relating to mediation analysis, procedures suggested by Baron and Kenny (1986) and Frazier et al. (2004) were followed. Specifically, to illustrate mediation, three regression equations are performed and four conditions were satisfied. Firstly, there is a significant relation between the contextual factor (independent variable) and RTC (dependent variable), by performing a simple linear regression between independent and dependent variable. Secondly, the contextual antecedent must be significantly related to perceived impact of change (mediator), by performing the second simple linear regression between independent and mediator variable. Thirdly, the mediator must be significantly related to RTC, by performing a multiple regression with both contextual factor and mediator are predictor variables; RTC is dependent variable. The last condition is to demonstrate that the strength of the relation between contextual factor and RTC is significantly weaker (which indicates partial mediation effects) or becomes statistically insignificant (which shows full mediation effect), when perceived impact of change is added in the model, by comparing unstandardized regression coefficients in the first and third equation.

Then, Sobel test is conducted, following Baron and Kenny's (1986) recommendations, to test whether the drop in unstandardized regression coefficients is statistically significant.

\section{Results and Discussion}

\subsection{Multiple Regression Results}

To test H1a, H2a, H3a, and H4a about the relationships between contextual factors and resistance to change, two regression models were carried out (M1, M2). Only M1 was found to be significant with $\mathrm{F}=15.845, \mathrm{p}<.01 .45 .8 \%$ of total variation in resistance to change was explained by total variations in four contextual variables in Model 1. 
Table 1: Multiple regression results

\begin{tabular}{|c|c|c|}
\hline & $\begin{array}{c}\text { M1 } \\
\beta \\
\text { (standardized) }\end{array}$ & $\begin{array}{c}\text { M2 } \\
\beta \\
\text { (standardized) }\end{array}$ \\
\hline \multicolumn{3}{|l|}{ Independent variable } \\
\hline Gender & & -.110 \\
\hline Age & & .042 \\
\hline Education & & .131 \\
\hline Information exchange & $-.241^{\star \star}$ & $-.255^{\star \star}$ \\
\hline Participation & $-.266^{* * *}$ & $-.285^{\star * *}$ \\
\hline Training & $-.273^{\star \star *}$ & $-.264^{\star * *}$ \\
\hline Trust in management & $-.212^{* *}$ & $-.211^{* *}$ \\
\hline R square & .458 & .467 \\
\hline Adjusted R square & .429 & .416 \\
\hline $\mathrm{F}$ & $15.845^{\star * *}$ & .419 \\
\hline
\end{tabular}

Note: ${ }^{* * *},{ }^{* *}$ and ${ }^{*}$ indicates significant at $1 \%, 5 \%$ and $10 \%$.

According to regression results in Model 1 , in terms of the relationships of contextual variables with resistance to change, all four contextual variables - information exchange, participation, training, and trust in management were negatively correlated with resistance to change with $\mathrm{p}<.05$, lending support to H1a, H2a, H3a, H4a. Also, when making comparison between absolute values of Beta standardized coefficients, the results demonstrated that among four contextual variables, training had the strongest impact, then participation, information exchange, and trust in management, respectively.

Discussing the findings, $\mathrm{H1a}, \mathrm{H} 2 \mathrm{a}, \mathrm{H} 3 \mathrm{a}, \mathrm{H} 4 \mathrm{a}$ received support from the data, which is consistent with previously empirical findings. When information exchange, participation and trust in management factors were re-tested in Lean transformation in the context of Vietnam and found similar findings with literature (Jimmieson et al., 2008; Kiefer, 2005); training was an underestimated factor in extant empirical studies, however, surprisingly, the factor was found to have the biggest impact to RTC, proving its significance in explaining RTC.

\subsection{Mediation Analysis}

To test H1b, H2b, H3b, H4b, four hypothesis testing mediation effects, three regression equations were performed to test four required conditions in establishing that perceived impact of change mediates the relation between contextual factors and RTC, following Baron and Kenny's (1986) and Frazier et al.'s (2004) guidelines, which was described in detail in the Methodology section.
Table 2: Regression results from investigating the mediating effect of perceived impact of change on information exchange and resistance to change

\begin{tabular}{|l|c|c|c|}
\hline Predictors & B & SE B & $\boldsymbol{\beta}$ \\
\hline $\begin{array}{l}\text { Step 1 } \\
\text { Information } \\
\text { exchange }^{\mathrm{a}}\end{array}$ & -.703 & .158 & $-.449^{* * *}$ \\
\hline $\begin{array}{l}\text { Step 2 } \\
\text { Information } \\
\text { exchange }\end{array}$ & .340 & .109 & $.334^{\text {b** }}$ \\
\hline $\begin{array}{l}\text { Step 3 } \\
\text { Perceived impact } \\
\text { of change } \\
\text { Information } \\
\text { exchange }\end{array}$ & -.658 & .148 & $-.428^{\text {a** }}$ \\
\hline
\end{tabular}

Notes: aDependent variable: resistance to change; 'Dependent variable: perceived impact of change. ${ }^{* *},{ }^{* *}$ and * indicates significant at $1 \%, 5 \%$ and $10 \%$.

To test H1b (Table 2), the first step shown a significant relationship between information exchange (dependent variable) and RTC (independent variable) with $\mathrm{p}<.01$, satisfying the first condition in testing mediation. The second step also revealed that information exchange is significantly related with perceived impact of change (mediator), with $\mathrm{p}$ $<.01$, which fulfilled the second condition. There was also a significant relationship between perceived impact of change and RTC, when both mediator and independent variables were included in the third equation, with $\mathrm{p}<.01$, indicating that the third condition was met.

In step 3, the effect of information exchange on RTC was smaller (absolute $\mathrm{B}=.479 ; \mathrm{p}<0.01$ ) than in step one (absolute $\mathrm{B}=.703 ; \mathrm{p}<0.01)$, meeting the fourth condition; however, it remained significant, demonstrating partial mediation effect. To assess whether this drop is significant, Sobel test was conducted. The result of Sobel test (Sobel $=-2.22 ; \mathrm{p}<.05$ ) shows that the decrease was statistically significant, suggesting the existence of partial mediation effects, showing support for H1b. Also, the indirect effect of the information exchange on RTC via perceived impact of change in this case was calculated to be -.22.

Discussing the findings, existed research in change management found inconsistency in findings in the relations between information exchange and resistance to change. This study contributed to the literature by showing findings of partial mediation effect of perceived impact of change to the relation between information exchange and behavioral resistance to change. To be specific, change recipients receiving timely, helpful and necessary information relating to the change programs, are less likely to oppose change initiative as they consider the benefits of the change outweighing the risks and decide to adapt to the change. 
Table 3: Regression results from investigating the mediating effect of perceived impact of change on participation and resistance to change.

\begin{tabular}{|c|c|c|c|}
\hline Predictors & B & SE B & $\beta$ \\
\hline $\begin{array}{l}\text { Step } 1 \\
\text { Participation }^{a}\end{array}$ & -.501 & .109 & $-.463^{* * *}$ \\
\hline $\begin{array}{l}\text { Step } 2 \\
\text { Participation }^{\mathbf{b}}\end{array}$ & .252 & .074 & $.358^{* * *}$ \\
\hline $\begin{array}{l}\text { Step } 3 \\
\text { Perceived impact } \\
\text { of change } \\
\text { Participation }\end{array}$ & $\begin{array}{l}-.643 \\
-.339\end{array}$ & $\begin{array}{l}.149 \\
.105\end{array}$ & $\begin{array}{l}-.418^{* * *} \\
-.313^{\star * *}\end{array}$ \\
\hline
\end{tabular}

Notes: a Dependent variable: resistance to change; ${ }^{b}$ Dependent variable: perceived impact of change. ${ }^{* * *},{ }^{* *}$ and ${ }^{*}$ indicates significant at $1 \%, 5 \%$ and $10 \%$.

Regression results to test $\mathrm{H} 2 \mathrm{~b}$ (Table 3), which examines the mediation effect of perceived impact of change on participation and RTC, show that the first two conditions for mediation were met. The absolute value of unstandardized regression coefficient of participation dropped to $.339(\mathrm{p}<.01)$ from $.501(\mathrm{p}<.01)$. The Sobel test indicates that this drop was statistically significant (Sobel $=-2.67, \mathrm{p}<.01)$, demonstrating partial mediation effect with the indirect effect of -.162. Therefore, H2b is supported by the data.

Discussing the findings, perceived impact of change mediates the relationship between participation and resistance to change. In other words, employees involving in decision-making process of the change initiative seems to be less likely to behave and reject the change, as they view expected benefits of the change as vital. This result could be explained by the argument made in hypothesis development based on the literature that, when employees participated in the change program, they have greater sense of control over the change and actively acquiring information relating to the change, which makes them view the change as beneficial, and reduces resistance.

Similar results were reached in H3b. Perceived impact of change partially mediates the relationship between training and RTC, shown in Table 4. P values from step 1,2, 3 indicated that the first three requirements for mediation effect were satisfied. Relating to the last condition, the absolute value of unstandardized regression coefficient decreased to $.432(\mathrm{p}<.01)$ from $.666(\mathrm{p}<.01)$ when accounting for the effect of mediator, indicating partial mediation effects. The decrease was reported to be statistically significant with Sobel $=-2.83, \mathrm{p}<0.01$ in Sobel test, which shows that H3b is supported. The calculated indirect effect was -.23 .
Table 4: Regression results from investigating the mediating effect of perceived impact of change on training and resistance to change

\begin{tabular}{|l|c|c|c|}
\hline Predictors & B & SE B & $\boldsymbol{\beta}$ \\
\hline $\begin{array}{l}\text { Step 1 } \\
\text { Training }\end{array}$ & -.666 & .142 & $-.470^{\text {a** }}$ \\
\hline $\begin{array}{l}\text { Step 2 } \\
\text { Training }\end{array}$ & .373 & .095 & $.405^{\text {b** }}$ \\
\hline $\begin{array}{l}\text { Step 3 } \\
\begin{array}{l}\text { Perceived impact } \\
\text { of change } \\
\text { Traininga }\end{array}\end{array}$ & -.626 & .153 & $-.407^{\text {*** }}$ \\
\hline
\end{tabular}

Notes: aDependent variable: resistance to change; 'Dependent variable: perceived impact of change. ${ }^{* * *},{ }^{* *}$ and ${ }^{*}$ indicates significant at $1 \%, 5 \%$ and $10 \%$.

Table 5: Regression results from investigating the mediating effect of perceived impact of change on trust in management and resistance to change

\begin{tabular}{|l|c|c|c|}
\hline Predictors & B & SE B & $\boldsymbol{\beta}$ \\
\hline $\begin{array}{l}\text { Step 1 } \\
\text { Trust in } \\
\text { management }\end{array}$ & -.766 & .165 & $-.465^{\text {*** }}$ \\
\hline $\begin{array}{l}\text { Step 2 } \\
\text { Trust in } \\
\text { management }\end{array}$ & .516 & .106 & $.483^{\text {b** }}$ \\
\hline $\begin{array}{l}\text { Step 3 } \\
\begin{array}{l}\text { Perceived impact } \\
\text { of change } \\
\text { Trust in } \\
\text { management }\end{array}\end{array}$ & -.613 & .163 & $-.399^{* * *}$ \\
\hline
\end{tabular}

Notes: a Dependent variable: resistance to change; ${ }^{b}$ Dependent variable: perceived impact of change. ${ }^{* * *},{ }^{* *}$ and ${ }^{*}$ indicates significant at $1 \%, 5 \%$ and $10 \%$.

Discussing the findings of $\mathrm{H} 3 \mathrm{~b}$, perceived change impact partially mediates the relationship between training and RTC. In short, change recipients receiving proper and necessary training, tools and knowledge relating to the change programs, are less likely to present objections and perform disrupting behavior towards the change, since they believe the change brings benefits rather than risks to the organization and to themselves. The mediation effect can be explained that training significantly improve employees' capabilities and expertise to implement the change, by which, they feel less threatened by the risk of change (e.g., losing jobs, disrupting daily works), started to recognize the change as significant, in turn, reduces resistance. 
Lastly, to test $\mathrm{H} 4 \mathrm{~b}$, the same procedures to test mediation effect were adopted as described in the Methodology section. Both step 1 and 2 indicated a significant relationship, with $\mathrm{p}$ $<.01$, meaning that the first two conditions were met. Step 3 also showed that the third requirement was satisfied when perceived impact of change was significantly related to RTC.

The effect of trust in management on RTC was smaller (absolute $\mathrm{B}=.449 ; \mathrm{p}<0.05$ ) than in step one (absolute $\mathrm{B}$ $=.766 ; \mathrm{p}<0.01$ ), meeting the fourth condition; however, it remained significant, also demonstrating partial mediation effect, with the indirect effect of -.3165 . This drop is also statistically significant with Sobel test (Sobel $=-2.97, \mathrm{p}<$ $.01)$. Therefore, the results support H4b.

Discussing the findings, this work contributed to the literature of that defined relationship by arguing that perceiving managers as reliable and exhibiting trust in management's capabilities and leadership to manage change affect employee's benefit-risk assessment of the change, resulting in a lower level of behavioral resistance to change. Also, the analysis testing mediation effect on four contextual variables indicate partial mediation effects only, which means that the mediator - the perceived impact of change - only accounted and explained to a certain extent of contextual factor and RTC, clearly showing that there is existence of other indirect effects and mediators.

\section{Conclusions}

The first four hypothesis (H1a, H2a, H3a, H4a) illustrate the relationships between four investigated contextual factors and RTC, which means that information exchange, participation, training, and trust in management are negatively correlated with RTC. This study contributed to the literature by empirically testing four contextual factors, especially training, in the context of Vietnam in Lean transformation. The least empirically investigated factor among four independent variables - training - showed the strongest impact, indicating its significance when explaining RTC. The four remaining hypotheses (H1b, H2b, H3b, H4b), developed with the purpose of answering the second research question, were also supported by the data. Though direct relationships between contextual factors and RTC were broadly examined especially with information exchange and participation, this work contributed to the body of knowledge that perceived change impact partially mediated all four relationships between contextual factors and RTC. In other words, perceived change impact accounted for some of the relationships between contextual factors and RTC. The biggest limitation of this study lies in its research design that significantly restricts the generalizability and representativeness of the study's findings, though the study successfully shows indepth findings in a narrowly-investigated context. Future studies should consider the concept of resistance to change in a larger sample size or adapting multiple-case design such as investigating RTC in two different types of changes or in different industries for a single type of organizational change.

\section{References}

Al-Haddad, S. \& Kotnour, T. (2015). Integrating the organizational change literature: a model for successful change. Journal of Organizational Change Management, 28(2), 234-262. https:// doi.org/10.1108/JOCM-11-2013-0215.

Armenakis, A.A., Bernerth, J.B., Pitts, J.P. \& Walker, H.J. (2007). Organizational change recipients' beliefs scale: development of an assessment instrument. Journal of Applied Behavioral Science, 43(2), 495-505. https://doi.org/10.1177\% 2F0021886307303654.

Ashford, S. (1988). Individual Strategies for Coping with Stress during Organizational Transitions. The Journal of Applied Behavioral Science, 24(1), 19-36. https://doi.org/10.1177\% 2F0021886388241005.

Atkinson, P. (2005). Managing resistance to change. Management Services, Spring, pp.14-19.

Azyan, Z., Pulakanam, V. \& Pons, D., 2017. Success factors and barriers to implementing lean in the printing industry: a case study and theoretical framework. Journal of Manufacturing Technology Management, 28(4). https://doi.org/10.1108/ JMTM-05-2016-0067.

Balogun, J., Hope-Hailey, V., Johnson, G., \& Scholes, K. (Eds.) (2008). Exploring Strategic Change (3rd ed.). Upper Saddle River, NJ: Prentice-Hall.

Baron, R. \& Kenny, D. (1986). The moderator-mediator variable distinction in social psychological research: Conceptual, strategic, and statistical considerations. Journal of Personality and Social Psychology, 51(6), 1173-1182. https://doi.apa.org/ doi/10.1037/0022-3514.51.6.1173.

Bartunek, J., Rousseau, D., Rudolph, J. \& DePalma, J. (2006). On the Receiving End: sense-making, emotion, and assessments of an organizational change initiated by others. The Journal of Applied Behavioral Science, 42(2), 182-206. https://doi.org/10. $1177 \% 2 \mathrm{~F} 0021886305285455$.

Benton, W.C. \& Shin, H. (1998). Manufacturing planning and control: the evolution of MRP and JIT integration. European Journal of Operational Research, 110(3), 411-440. https://doi. org/10.1016/S0377-2217(98)00080-0.

Bhasin, S. \& Burcher, P. (2006), Lean viewed as a philosophy. Journal of Manufacturing Technology Management, 17(1), 5672. https://doi.org/10.1108/17410380610639506.

Bovey, W. \& Hede, A. (2001). Resistance to organizational change: the role of cognitive and affective processes. Leadership \& Organization Development Journal, 22(8), 372-382. https://doi. org/10.1108/01437730110410099.

Burnes, B. (2014). Understanding Resistance to Change - Building on Coch and French. Journal of Change Management, 15(2), 92-116. https://doi.org/10.1080/14697017.2014.969755. 
Caldwell, S.D., Herold, D.M. \& Fedor, D.B. (2004). Toward an understanding of the relationships among organizational change, individual differences, and changes in personenvironment fit: a cross-level study. Journal of Applied Psychology, 89(5), 868-882. https://doi.org/10.1037/00219010.89.5.868

Camagu, S. (2010). Investigating factors that negatively influence lean implementation in the eastern cape automotive industry. Master's thesis, Faculty of Business and Economic Sciences, Nelson Mandela Metropolitan University, Port Elizabeth, South Africa.

Canning, J. \& Found, P. (2015). The effect of resistance in organizational change programmes. International Journal of Quality and Service Sciences, 7(2/3), 274-295. https://doi. org/10.1108/IJQSS-02-2015-0018.

Clegg, B., Rees, C. \& Titchen, M. (2010), A study into the effectiveness of quality management training: a focus on tools and critical success factors. TQM Journal, 22(2), 188-208. https://doi.org/10.1108/17542731011024291.

Coch, L. and French, J. (1948). Overcoming Resistance to Change. Human Relations, 1, 512-532. https://doi.org/10.1177\% 2F001872674800100408.

Coetsee, L. (1999). From resistance to commitment. Public Administration Quarterly, 23(2), 204-222. https://www.jstor. org/stable/i40038767.

Cornell, J.E. \& Herman, S.M. (1989). Change or get changed. Organization Development Journal, 7(4), 76-81.

Cudney, E. \& Elrod, C. (2010), Incorporating lean concepts into supply chain management, International Journal of Six Sigma and Competitive Advantage, 6(1/2), 12-30. https://doi. org/10.1504/IJSSCA.2010.034854.

Cunningham, C.E., Woodward, C.A., Shannon, H.S., MacIntosh, J., Lendrum, B., Rosenbloom, D. \& Brown, J. (2010). Readiness for organizational change: a longitudinal study of workplace, psychological and behavioural correlates. Journal of Occupational and Organizational Psychology, 75(4), 377392. https://doi.org/10.1348/096317902321119637.

Decker, P., Durand, R., Mayfield, C., McCormack, C., Skinner, D. \& Perdue, G. (2012). Predicting implementation failure in organization change. Journal of Organizational Culture, Communications and Conflict, 16(2), 29-49.

Dent, E. \& Goldberg, S. (1999). Challenging "Resistance to Change". The Journal of Applied Behavioral Science, 35(1), 25-41. https://doi.org/10.1177\%2F0021886399351003.

Dora, M., Kumar, M., Van Goubergen, D., Molnar, A. \& Gellynck, X. (2013). Operational performance and critical success factors of lean manufacturing in European food processing SMEs. Trends in Food Science and Technology, 31(2), 156-164. https://doi.org/10.1016/j.tifs.2013.03.002.

Erwin, D. \& Garman, A. (2010). Resistance to organizational change: linking research and practice. Leadership \& Organization Development Journal, 31(1), 39-56. DOI:10.1108/01437731011010371.
Eswaramoorthi, M., Kathiresan, G.R., Prasad, P.S.S. \& Mohanram, P.V. (2011). A survey on lean practices in Indian machine tool industries. International Journal of Advance Manufacturing Technology, 52(12), 1091-1101. https://doi.org/10.1007/ s00170-010-2788-y.

Fedor, D.B., Caldwell, S. \& Herold, D.M. (2006). The effects of organizational changes on employee commitment: a multilevel investigation. Personnel Psychology, 59(1), 1-29. https://doi. org/10.1111/j.1744-6570.2006.00852.x.

Field, A., 2013. Discovering Statistics Using IBM SPSS Statistics (4th ed). London, UK: Sage Publications.

Fiorelli, J.S. \& Margolis, H. (1993). Managing and understanding large systems change: guidelines for executives and change agents. Organization Development Journal, 11(3), 1-13.

Frazier, P., Tix, A. \& Barron, K. (2004). Testing Moderator and Mediator Effects in Counseling Psychology Research. Journal of Counseling Psychology, 51(1), 115-134. https://doi.apa.org/ doi/10.1037/0022-0167.51.1.115.

Giangreco, A. \& Peccei, R. (2005). The nature and antecedents of middle manager resistance to change: evidence from an Italian context. International Journal of Human Resource Management, 16(10), 1812-1829. https://doi. org/10.1080/09585190500298404.

Herold, D.M., Fedor, D.B. \& Caldwell, S.D. (2007). Beyond change management: a multilevel investigation of contextual and personal influences on employees' commitment to change. Journal of Applied Psychology, 92(4), 942-951. https://doi.apa. org/doi/10.1037/0021-9010.92.4.942.

Holt, D.T., Armenakis, A.A., Field, H.S. \& Harris, S.G. (2007). Readiness for organizational change. Journal of Applied Behavioral Science, 43(2), 232-255. https://doi.org/10.1177\% 2F0021886306295295.

Huang, C. \& Huang, I. (2009). Resistance to change: The effects of organizational intervention and characteristic. Review of Business Research, 9(1), 110-114.

Jacobs, G. \& Keegan, A., 2016. Ethical Considerations and Change Recipients' Reactions: 'It's Not All About Me'. Journal of Business Ethics, 152(1), 73-90. DOI: 10.1007/s10551-0163311-7.

Jadhav, J., Mantha, S. \& Rane, S., 2014. Exploring barriers in lean implementation. International Journal of Lean Six Sigma, 5(2), 122-148. https://doi.org/10.1108/IJLSS-12-2012-0014.

Jermier, J., Knights, D. \& Nord, W. (1994). Resistance and power in organizations. New York, NY: Routledge.

Jimmieson, N.L., Peach, M. \& White, K.M. (2008). Utilizing the theory of planned behaviour to inform change management: an investigation of employee intentions to support organisational change. The Journal of Applied Behavioral Science, 44(2), 237-262. https://doi.org/10.1177\%2F0021886307312773.

Jorgensen, H., Owen, L. \& Heus, A. (2009). Stop improvising change management. Strategy \& Leadership, 37(2), 38-44. https://doi.org/10.1108/10878570910941217. 
Kiefer, T. (2005). Feeling bad: antecedents and consequences of negative emotions in ongoing change. Journal of Organizational Behavior, 26(8), 875-897. https://doi.org/10.1002/job.339.

Kumari, N. (2017). Organizational Diagnosis: A Case of Infosys, India. Journal of Asian Finance, Economics and Business, 5(1), 53-62. http://dx.doi.org/10.13106/jafeb.2018.vol5.no1.53.

Lewin, K. (1947). Frontiers in Group Dynamics. Human Relations, $1(1), 5-41$.

Lewis, J.D. \& Weigert, A. (1985). Trust as a social reality. Social Forces, 63(4), 967-985. https://doi.org/10.2307/2578601.

Lewis, L. (2006), Employee perspectives on implementation communication as predictors of perceptions of success and resistance. Western Journal of Communication, 70(1), 23-46. https://doi.org/10.1080/10570310500506631.

Lines, R. (2004). Influence of participation in strategic change: resistance, organizational commitment and change goal achievement. Journal of Change Management, 4(3), 193-215. https://doi.org/10.1080/1469701042000221696.

Mabin, V., Forgeson, S. \& Green, L. (2001). Harnessing resistance: using the theory of constraints to assist change management. Journal of European Industrial Training, 25(2), 168-191. https://doi.org/10.1108/EUM0000000005446.

Marodin, G.A. \& Saurin, T.A. (2013). Implementing lean production systems: research areas and opportunities for future studies. International Journal of Production Research, 51(22), 6663-6680. https://doi.org/10.1080/00207543.2013.826831.

Meaney, M. \& Pung, C. (2008). McKinsey global results: creating organizational transformations. The McKinsey Quarterly. pp.17.

Michel, A., Todnem, R. \& Burnes, B. (2013). The limitations of dispositional resistance in relation to organizational change. Management Decision, 51(4), 761-780. https://doi. org/10.1108/00251741311326554.

Miller, V., Johnson, J. \& Grau, J. (1994). Antecedents to willingness to participate in a planned organizational change. Journal of Applied Communication Research, 22(1), 59-80. https://doi. org/10.1080/00909889409365387.

Mohanty, R.P., Yadav, O.P. \& Jain, R. (2007), Implementation of lean manufacturing principles in auto industry. VilakshanXIMB Journal of Management, 1-32. https://doi.org/10.1016/j. promfg.2019.04.043.

Msweli-Mbanga, P. \& Potwana, N. (2006). Modelling participation, resistance to change, and organisational citizenship behaviour: A South African case. South African Journal of Business Management, 37(1), 21-29. https://doi.org/10.4102/sajbm. v37i1.595.

Netland, T.H. (2016). Critical success factors for implementing lean production: the effect of contingencies. International Journal of Production Research, 54(8), 2433-2448. https://doi.org/10.1 080/00207543.2015.1096976.

Nguyen, T.L.H., Pham, N.T., Dao, V.P.L., Ngo, T.T.T. \& Le, T.T.B. (2020). Critical Factors Affecting the Innovation Activities of Businesses: Evidence from Binh Dinh Province, Vietnam. Journal of Asian Finance, Economics and Business, 7(7), 425438. https://doi.org/10.13106/jafeb.2020.vol7.no7.425.

Oreg, S. (2003). Resistance to change: Developing an individual differences measure. Journal of Applied Psychology, 88(4), 680-693. https://doi.org/10.1037/0021-9010.88.4.680.

Oreg, S. (2006). Personality, context, and resistance to organizational change. European Journal of Work and Organizational Psychology, 15(1), 73-101. https://doi. org/10.1080/13594320500451247.

Oreg, S., Vakola, M. \& Armenakis, A. (2011). Change Recipients' Reactions to Organizational Change. The Journal of Applied Behavioral Science, 47(4), 461-524. https://doi.org/10.1177\% 2F0021886310396550.

Pakdil, F. \& Leonard, K.M. (2015). The effect of organizational culture on implementing and sustaining lean processes. Journal of Manufacturing Technology Management, 26(5), 725-743. https://doi.org/10.1108/JMTM-08-2013-0112.

Piderit, S. (2000). Rethinking Resistance and Recognizing Ambivalence: A Multidimensional View of Attitudes toward an Organizational Change. The Academy of Management Review, 25(4), 783-94. https://doi.org/10.2307/259206.

Portioli-Staudacher, A. \& Tantardini, M. (2012). Investigating the main problems in implementing Lean in supply chains of service companies. International Journal of Services and Operations Management, 11(1), 87-106. https://doi. org/10.1504/IJSOM.2012.044801.

Schweiger, D.M. \& DeNisi, A.S. (1991). Communication with employees following a merger: a longitudinal field experiment. Academy of Management Journal, 34(1), 110-35. https://doi. org/10.5465/256304.

Sim, K.L. \& Chiang, B. (2012). Lean production systems: resistance, success and plateauing. Review of Business, 33(1), 97-110.

Singh, B., Garg, S.K. \& Sharma, S.K. (2010). Scope for lean implementation: a survey of 127 Indian industries. International Journal of Rapid Manufacturing, 1(3), 323-333. https://doi. org/10.1504/IJRAPIDM.2010.034253.

Staudacher, A.P. \& Tantardini, M. (2007). Lean production Implementation: a survey in Italy. In: International Conference on Industrial Engineering and Industrial Management. Madrid, Italy.

Trang, T.V. \& Do, Q.H. (2020). Critical Success Factors of TQM Implementation in Vietnamese Supporting Industries. Journal of Asian Finance, Economics and Business, 7(7), 391-401. https://doi.org/10.13106/jafeb.2020.vol7.no7.391.

Vakola, M. (2014). What's in there for me? Individual readiness to change and the perceived impact of organizational change. Leadership \& Organization Development Journal, 35(3), 195209. https://doi.org/10.1108/LODJ-05-2012-0064.

Van Dam, K., Oreg, S. \& Schyns, B. (2008). Daily work contexts and resistance to organizational change: the role of leadermember exchange, development climate, and change process 
characteristics. Applied Psychology: An International Review, $\quad 57(2), \quad 313-34 . \quad$ https://doi.org/10.1111/j.14640597.2007.00311.x.

Wanberg, C. \& Banas, J., 2000. Predictors and outcomes of openness to changes in a reorganizing workplace. Journal of Applied Psychology, 85(1), 132-142. https://doi.org/10.1037/00219010.85.1.132.

Weller, S. and Bernadine, V. (2007). Attitudes towards workplace change in the Australian higher education sector: a tale of divergence and a case for reform. New Zealand Journal of Employment Relations, 32(2), 53-68.
Womack, J. \& Jones, D. (2003). Lean thinking: Banish Waste and Create Wealth in Your Corporation. Free Press, New York, NY (Simon \& Schuster).

Womack, J., Jones, D. and Ross, D. (1990), The Machine that Changed the World: Based on the Massachusetts Institute of Technology 5-Million Dollar 5-Year Study on the Future of the Automobile, Rawson Associates, New York, NY.

Zahra, G., Mehrdad, A., Charles, P., Nahid, H., Payam, F. and Haleh, G., 2018. Factors Affecting Resistance to Change among Hospital Staff using a Structural Equation Modeling Technique. Journal of Health Management and Informatics, 5(4), 125-136. 